\title{
Field Immobilization of Molina's Hog-nosed Skunk (Conepatus chinga) Using Ketamine and Xylazine
}

Diego F. Castillo, ${ }^{1,3}$ Estela Luengos Vidal, ${ }^{1}$ Emma B. Casanave, ${ }^{1,2}$ and Mauro Lucherini ${ }^{1,2}{ }^{1}$ Grupo de Ecología Comportamental de Mamíferos-Cátedra de Fisiología Animal, Departamento de Biología, Bioquímica y Farmacia, Universidad Nacional del Sur, San Juan 670, Bahía Blanca (8000), Argentina; ${ }^{2}$ Consejo Nacional de Investigaciones Científicas y Técnicas (CONICET); ${ }^{3}$ Corresponding author (email: diefcastillo@ gmail.com)

ABSTRACT: We injected 27 adult Molina's hognosed skunks (Conepatus chinga) intramuscularly by hand with ketamine hydrochloride (KH) and xylazine hydrochloride (XH) in the Pampas grassland of Argentina. Skunks were immobilized with a mean $( \pm S D)$ dosage of $24.9 \pm 6.5 \mathrm{mg} / \mathrm{kg} \mathrm{KH}$ and $1.9 \pm 0.6 \mathrm{mg} / \mathrm{kg} \mathrm{XH}$. The mean effective dosages of $\mathrm{KH}(27.6 \mathrm{mg} / \mathrm{kg})$ and $\mathrm{XH}(1.7 \mathrm{mg} / \mathrm{kg})$ were higher and lower, respectively, than those reported in skunks previously. Mean induction and recovery time were $5.3 \pm 1.9 \mathrm{~min}$ and $47.7 \pm 18.5 \mathrm{~min}$, respectively. Hypothermia was the only problem detected in field immobilization and occurred in winter but did not appear to be associated with to drug doses. We conclude that $\mathrm{KH} / \mathrm{XH}$ is a safe immobilizing drug combination for Molina's hog-nosed skunk.

Key words: Hypothermia, immobilization, Mephitidae, Pampas grassland.

Field immobilization of mammals is often required for examination, identification, and attachment of radiocollars. Ketamine hydrochloride ( $\mathrm{KH})$ is a commonly used anesthetic in wildlife and creates a dissociative anesthesia (West et al., 2007). Ketamine has a rapid, dose-dependent effect that can vary from immobilization to a surgical plane of anesthesia and has a wide safety margin, minimal respiratory effect, and minimal cardiovascular effect (Kreeger,1996). However, Ketamine can cause hematologic alterations, copious salivation, and poor muscle relaxation (Kreeger, 1996). The poor muscle relaxation of $\mathrm{KH}$ can be mediated by adding drugs with tranquillizer or muscle relaxation effect. Xylazine hydrochloride (XH) is a nonnarcotic sedative analgesic (West et al., 2007) inducing cardiovascular and respiratory depression. Mixtures of KH and XH often result in smooth induction and recovery in many species (e.g., Harthoorn, 1976; Belant, 1995; Kreeger, 1996).
The Molina's hog-nosed skunk (Conepatus chinga) is a small mephitid with an average adult body weight of $1.4 \mathrm{~kg}$ (Castillo et al., 2011). It has a wide distribution in South America ranging from Peru, Bolivia, Uruguay, and western Paraguay to at least as far south as Neuquén province in Argentina and central Chile (Redford and Eisenberg, 1992). However, information about the biology of C. chinga is scarce (Castillo et al., 2011). This is the first report of use of $\mathrm{XH}$ and KH in Molina's hog-nosed skunks (skunks, hereafter) for field immobilization.

Live trapping was conducted from December 1998 to February 2007 in the Pampas grassland of central Argentina. During 1998-2003, we used mesh-wire box traps and soft-padded leg-hold traps (Victor soft catch, 1 1/2 (Oneida Victor, Euclid, Ohio, USA), but, in spite of a relatively large trapping effort (4,857 trap nights), only 12 individuals were captured. From 2004 to 2007, we spotlighted skunks from a vehicle and restrained them manually, using a blanket to avoid being sprayed. All skunks were immobilized via hand syringe at the capture site.

Each skunk was intramuscularly injected with a 9.3:1 (28:3 $\mathrm{mg})$ combination of KH (Ketalar, Parke-Davis, Morris Plains, New Jersey, USA) and XH (Rompun, Mobay Corp., Animal Health Division, Shawnee, Kansas, USA). If required, an additional injection with $50 \%$ of the initial doses of $\mathrm{KH}$ was used to maintain anesthesia, as recommended by Kreeger (1996). Respiratory rate, heart rate, and rectal temperature were taken as soon as practical after immobilization. Subsequently, these parameters were taken at 
10-min intervals until handling was completed. A commercial ointment (Lacryvisc gel, Alcon Laboratorios S.A., D.F, Mexico) was applied to the eyes to lubricate the cornea and conjunctiva and prevent their desiccation, and a cloth was placed over the eyes to minimize the risk of injuries from light. Weight and morphologic measurements were recorded (Castillo et al., 2011). Eighteen adult skunks were fitted with radiocollars (Telemetry Solutions, Concord, California, and AVM Instrument, Colfax, California), and skunks were released at the capture site after complete recovery from anesthesia.

Induction time was recorded as the time from injection until sternal or lateral recumbency was attained (Belant, 1991; Lopez Gonzalez et al., 1998), and recovery time was the interval between recumbency and the recovery of an animal's ability to maintain an upright posture (Belant, 1991; Lopez Gonzalez et al., 1998). Criteria for an effective anesthesia dose included: 1) mean induction time $<11$ min; 2) anesthesia of sufficient depth to allow safe and comfortable handling for at least $15 \mathrm{~min}$; and 3) normal cardiac and respiratory rate and rhythm. Skunks were considered to be hypothermic when rectal temperatures were below $35 \mathrm{C}$ and hyperthermic above $40 \mathrm{C}$ (West et al., 2007).

We compared initial temperature between hypothermic and normothermic skunks using Mann-Whitney $U$-tests. This test was also used to evaluate differences in mean heart and respiratory rate across genders. A $t$-test was used to compare $\mathrm{XH}$ and $\mathrm{KH}$ doses administered to hypothermic and normothermic animals. For all statistical tests, we used SPSS Statistics version 17 (SPSS Inc., Chicago, Illinois, USA), and $P<0.05$ was considered significant.

We captured 27 adult skunks (12 males, 15 females) from December 1998 to March 2007. The overall mean doses of $\mathrm{KH}$ and $\mathrm{XH}$ were $24.9 \mathrm{mg} / \mathrm{kg}$ (range $=10-40 \mathrm{mg} / \mathrm{kg}$ ) and $1.9 \mathrm{mg} / \mathrm{kg}$ (range=1.2-2.9 mg/kg), respectively. Male mean doses (means \pm $\mathrm{SD})$ of $\mathrm{KH}$ and $\mathrm{XH}$ were $22.3 \pm 7.1 \mathrm{mg} / \mathrm{kg}$ and $2.0 \pm 0.7 \mathrm{mg} / \mathrm{kg}$, respectively. Female doses were $26.0 \pm 4.5 \mathrm{mg} / \mathrm{kg}$ for $\mathrm{KH}$ and $1.8 \pm 0.5 \mathrm{mg} / \mathrm{kg}$ for XH. Seventeen animals $(63 \%)$ were effectively anesthetized with single injections using an average of $27.6 \mathrm{mg} / \mathrm{kg}$ (range $=20-40 \mathrm{mg} / \mathrm{kg}$ ) for $\mathrm{KH}$ and $1.7 \mathrm{mg} / \mathrm{kg}$ (range $=1.2-2.7 \mathrm{mg} / \mathrm{kg}$ ) for XH. Effective dosages were $28.6 \pm 4.9 \mathrm{mg} /$ $\mathrm{kg}(\mathrm{KH})$ and $1.7 \pm 0.6 \mathrm{mg} / \mathrm{kg}(\mathrm{XH})$ for males $(n=7)$ and $26.7 \pm 3.6 \mathrm{mg} / \mathrm{kg}(\mathrm{KH})$ and $1.7 \pm 0.5 \mathrm{mg} / \mathrm{kg}(\mathrm{XH})$ for females $(n=10)$.

Mean induction time was $5.3 \mathrm{~min}$ (range $=2-10 \mathrm{~min}$ ) and mean recovery time was $47.9 \mathrm{~min}$ (range $=27-85 \mathrm{~min}$ ). Induction time and recovery time (means \pm SD) were $7.0 \pm 2.4$ and $46.3 \pm 17.2 \mathrm{~min}$, respec-

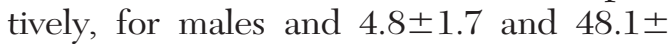
$18 \mathrm{~min}$, respectively, for females. The 10 animals that were not effectively anesthetized with single doses received an average total of $20.1 \mathrm{mg} / \mathrm{kg}$ ( range $=16.6-25.0 \mathrm{mg}$ / $\mathrm{kg}$ ) and $2.3 \mathrm{mg} / \mathrm{kg}$ ( range $=1.3-2.8 \mathrm{mg} / \mathrm{kg}$ ), for $\mathrm{KH}$ and $\mathrm{XH}$, respectively. In these cases, supplemental KH was given with a mean dose of $25.8 \mathrm{mg} / \mathrm{kg}$ (range= $10.0-46.7 \mathrm{mg} / \mathrm{kg}$ ).

The mean initial rectal temperature after anesthesia was $36.4 \mathrm{C}(34.0-38.1 \mathrm{C}$, $n=27$ ). None of the captured animals developed hyperthermia during handling, and only two exceeded $38 \mathrm{C}$. Nine $(35.7 \%)$ skunks were hypothermic during handling. The initial temperature of the hypothermic animals averaged 35.3 $\pm 1.0 \mathrm{C}$ and was significantly lower than for skunks that maintained normal temperatures of $37.1 \pm 0.7 \mathrm{C} \quad\left(U=14.5 n_{1}=18, n_{2}=10\right.$, $P<0.001)$. No significant differences were found in doses of $\mathrm{KH}(t=-0.12, d f=25$, $P=0.99)$ and XH $(t=1.4, d f=25, P=0.17)$ administered to hypothermic animals compared with normothermic animals. Hypothermia was observed in $80 \%$ of the skunks captured in winter (JuneSeptember).

Mean heart rate during handling was $177.1 \pm 46.9$ beats/min $(n=27)$, whereas the mean initial heart rate was $188.7 \pm 43.3$ beats/min, with no significant differences between sexes $\left(U=77, n_{1}=11\right.$, 
$\left.n_{2}=5, P=0.79\right)$. No significant difference was found between males and females $\left(U=32.5, n_{1}=9, n_{2}=0, P=0.31\right)$ in initial respiratory rate $(49.9 \pm 21.9$ breaths $/ \mathrm{min})$. Mean respiratory rate during handling was $49.2 \pm 21.6$ breaths/min $(n=19)$.

No adverse, short-term effects were detected after drug administration, with the exception of hypothermia. Decreasing body temperature can result in apnea and eventual death if it is not corrected (Evans, 2002). However, in this study, hypothermia was likely a result of exposure to low ambient temperatures. Although no skunks died during anesthesia, hypothermia required extending the duration of immobilization to ensure that the body temperature normalized before releasing the animal. Working inside of a tent, application of hot packs to the body, and use of a camp stove to heat the tent were effective in warming hypothermic skunks. None of the skunks that were hypothermic and subsequently radio-tracked showed any abnormal behavior after release compared with normothermic skunks.

Our results suggest that field immobilization of $C$. chinga with ketamine-xylazine is effective and safe. The anesthesia period using this drug combination was sufficient for taking morphometric measurements, collecting biologic samples, and attaching radiocollars. Unfortunately, the lack of published data on this species prevented evaluation of physiologic effects of this drug combination. It is clear that attention to body temperature is important, especially in cold weather. The data presented in this study are the first published for immobilization of C. chinga and represent an important step for capture and handling procedures in management and conservation of Conepatus skunks.

We thank M. Uhart, C. Marull, E. Ferreira, and S. Minini for technical help in captures. C. Manfredi, J. Reppucci, N. Caruso, S. Savini, D. Birochio, M. Rodriguez, H. Bindotti, R. Temperoni, H.
Marrero, and the Merino family provided field support. E.L.V. was supported by a postgraduate scholarship from Consejo Nacional de Investigaciones Científicas y Técnicas (CONICET) and D.F.C. by postgraduate scholarships from Comisión de Investigaciones Científicas and CONICET. The paper was funded by Earthwatch Institute, IM40 Grant by ANPCyT, and SGCyT, UNS (24B152).

\section{LITERATURE CITED}

BELANT, J. 1991. Immobilization of fishers (Martes pennanti) with ketamine hydrochloride and xylazine hydrochloride. Journal of Wildlife Diseases 27: 328-330.

- 1995. Field immobilization of raccoons with ketamine hydrochloride and xylazine hydrochloride. Acta Theriologica 40: 327-330.

Castillo, D. F., M. Lucherini, E. M. Luengos Vidal, C. Manfredi, and E. B. Casanave. 2011. Spatial organization of Molina's hog-nosed skunk (Conepatus chinga) in two landscapes of the Pampas grassland of Argentina. Canadian Journal of Zoology 89: 229-238.

Evans, R. H. 2002. Raccoons and relatives (Carnivora, Procyonidae). In Zoological restraint and anesthesia, D. Heard (ed.). International Veterinary Information Service, Ithaca, New York, http://www.ivis.org/special_books/Heard/evans/ chapter_frm.asp?LA_1. Accessed September 2011.

Harthoorn, A. M. 1976. The chemical capture of animals. Bailliere Tindall, London, UK, 416 pp.

Kreeger, T. J. 1996. Handbook of wildlife chemical inmobilization. Wildlife Pharmaceuticals Inc., Fort Collins, Colorado, $342 \mathrm{pp}$.

Lopez Gonzalez, C., A. Gonzalez-Romero, J. Laundre, L. Cantu Salazar, M. Hidalgo Mihart, A. De Villa Meza, E. Martinez Meyer, and M. Casariego Madorell. 1998. Field immobilization of pygmy spotted skunks from Mexico. Journal of Wildlife Diseases 34: 186189

Redford, K. H., And J. F. Eisenberg. 1992. Mammals of the Neotropics: The southern cone. University of Chicago Press, Chicago, Illinois, $430 \mathrm{pp}$.

West, G., D. J. Heard, and N. Caulkett. 2007. Zoo animal and wildlife immobilization and anesthesia. Wiley-Blackwell, Ames, Iowa, 718 pp.

Submitted for publication 18 February 2011.

Accepted 26 August 2011 